\title{
EFFECT OF DIABETES AND GLUCOSE VARIABILITY ON FALL-RISK IN THE HOSPITAL POPULATION
}

\author{
C. Berra' ${ }^{1}$, F. Zangrandi'2, F. De Fazio ${ }^{2}$, M. Mirani ${ }^{1}$, G. Favacchio ${ }^{1}$, M. Albini' ${ }^{2}$, P. Meroni ${ }^{2}$, F. Folli ${ }^{3}$
}

1) Metabolic diseases unit and 2) Quality Monitoring Office, Humanitas Clinical and Research Center (Rozzano Italy) and 3) University of Milan

\section{BACKGROUND}

Patient's falls are the most frequent adverse events in hospitals, with severe consequences such as the compromise of physical and mental well-being and increa sed in-patient time which further increases economic and social costs. Previous studies have suggested that severe hypoglycemia is associated with risk of falls, both in type 1 as well as type 2 diabetic subjects, irrespective of age $(1,2)$. Elderly subjects with and without diabetes also have increased risk for falls, fall-rela ted fractures, seizures and comas and exacerbation of chronic conditions, such as cognitive dysfunction and cardiac events which leads to hospitalization (3, 4). Moreover, increased glycemic variability during hospitalization was found to be independently associated with longer length of stay and increased mortality in noncritically ill patients $(5,6)$. Little is known about how glycemic variability and other risk factors could be associated with falls in hospitalized population.

\section{AIM OF THE STUDY}

To investigate the role of hypoglycemia (glucose $<70 \mathrm{mg} / \mathrm{dl}$ ) or hyperglycemia (glucose $>200 \mathrm{mg} / \mathrm{dl}$ ), or the combination of both, as independent risk factors for falls in a hospitalized population.

\section{MATHERIAL AND METHODS}

We performed a retrospective cohort study that included all subjects admitted in Humanitas Research Hospital, Milano, Italy from January 2015 to December 2016 (2 years). Patients admitted to the intensive care units were excluded. Analysis were performed on all glucose readings available during each individual hospitalizations. Approval of the Institutional Review Board was obtained. All capillary glucose values were analyzed (when present) in patients who had a fall and those which did not fall (fall population and non-fall population). We have considered the presence of value of capillary blood glucose $>200 \mathrm{mg} / \mathrm{dl}$ and $<70 \mathrm{mg} / \mathrm{dl}$, as an indication of glycemic variability, in the hypoglycemic or hyperglycemic range. The obtained data were subjected to multivariate analysis matched for sex, age, admission to hospital (from emergency care or elective) surgical or medical admission and discharge diagnosis.

\section{RESULTS}

We analyzed medical records of 57411 subjects: mean age was 60.7 (50-74), 52.7\% male ( $\mathrm{n}=30271)$ and $47.3 \%$ females $\mathrm{n}=27140.62 .4 \%$ were admitted to the hospital for medical diseases $(\mathrm{n}=35804)$ while $37.6 \%$ were surgical patients. $23.7 \%(\mathrm{n}=13605)$ were admitted in the hospital from emergency room. By employng the Charlson index as a degree of complexity of the admissions, $11.7 \%$ had score $=2$ while $6.6 \%$ scored 1 and $81.7 \%$ scored 0 .

Table 1. Among the 57411 subjects studied 759 had a fall during the hospital stay. The number of patients at least with one capillary glucose determination in the non fall population $(\mathrm{N}=56652)$ was $13025(23 \%)$; while in the fall population $(\mathrm{N}=759)$ was $385(50,7 \%) .(\mathrm{p}<0.001)$

\begin{tabular}{|r|r|r|r|r|}
\hline & $\begin{array}{c}\text { no glucose } \\
\text { determination }\end{array}$ & $\begin{array}{r}\text { one glucose } \\
\text { determination }\end{array}$ & Total & $\begin{array}{c}\text { one glucose } \\
\text { determination }\end{array}$ \\
\hline Non fall population & 43627 & 13025 & 56652 & $23,0 \%$ \\
\hline Fall population & 374 & 385 & 759 & $50,7 \%$ \\
\hline Total & 44001 & 13410 & 57411 & \\
\hline$\%$ falls & $0,8 \%$ & $2,9 \%$ & & \\
\hline
\end{tabular}

\begin{tabular}{|c|c|c|c|c|}
\hline & $\begin{array}{c}\text { glucose }<70 \text { o } \\
>200 \mathrm{mg} / \mathrm{dl}\end{array}$ & $\begin{array}{l}70<\text { glucose } \\
>200 \mathrm{mg} / \mathrm{dl}\end{array}$ & Total & \\
\hline Fall population & 243 & 142 & 385 & \\
\hline Non fall-population & 6412 & 6613 & 13025 & \\
\hline Total & 6655 & 6755 & 13410 & \\
\hline \multirow[t]{2}{*}{ Odds ratio } & 1,76 & 1,42 & 2,19 & $\begin{array}{r}\operatorname{Pr}>\operatorname{chi} 2= \\
0.0000 \\
\end{array}$ \\
\hline & $\begin{array}{l}\text { Diabetic } \\
\text { medications }\end{array}$ & $\begin{array}{c}\mathrm{NO} \\
\text { treatment } \\
\text { for diabetes }\end{array}$ & Total & \\
\hline Fall population & 233 & 526 & 759 & \\
\hline Non fall population & 7346 & 49306 & 56652 & \\
\hline Total & 7579 & 49832 & 57411 & \\
\hline Odds ratio & 2,97 & 2,54 & 3,49 & $\begin{array}{r}\operatorname{Pr}>\operatorname{chi} 2= \\
0.0000 \\
\end{array}$ \\
\hline
\end{tabular}

Table 2. Among the fall-population subgroup, which had at least one capillary glucose measurement, 243 subjects out of a total of $385(63,1 \%)$ had a value less than $70 \mathrm{mg} / \mathrm{dl}$ or higher than $200 \mathrm{mg} / \mathrm{dl}$, while in the non fall population, 6412 out of 13025 subjects $(49,2 \%)$. had values out of the 70 to $200 \mathrm{mg}$ range Patients with at least one glycemic value out of the range $(>200 \mathrm{mg} /$ $\mathrm{dl}$ and $<70 \mathrm{mg} / \mathrm{dl}$ ) had a 1.76 odd ratio of falls as compared to the well compensated subjects (glucose values 70-200 mg/dl) (confidence interval between 1.42 and $2.19 ; \mathrm{p}<0.001$ ).

Table 3. Considering the subjects treated with diabetes medications ( $N=7579)$, (hypoglycemic agents including insulin), prescription of treatment was significantly correlated with value of glucose $>200 \mathrm{mg} / \mathrm{dl}$ and $<70 \mathrm{mg} / \mathrm{dl}$. 233 out of $7579(3.07 \%)$ had a fall, while in the subjects not receiving hypoglycemic agents, the percentage of falls was $1.05 \%$ (526 on 49832) (odds ratio 2.97, confidence interval between 2.54 and $3.49 ; \mathrm{p}<0.001$ ). Insulin treatment was more significantly correlated with the risk of falls. Data not shown.

Table 4. After multivariate analysis for sex, age, admission to hospital (from ER/elective) surgical or medical and discharge diagnosis, the presence of at least one glycemic value out of the range confers an odd-ratio for fall of 1.5 (confidence interval between 1.20 and $1.86 ; \mathrm{p}<0.001$ ).

\begin{tabular}{|r|r|r|r|r|}
\hline & \multicolumn{1}{|c|}{$\begin{array}{c}\text { Odds } \\
\text { Ratio }\end{array}$} & Inf 95\% & \multicolumn{1}{c|}{$\begin{array}{c}\text { Sup } \\
\text { I5\% }\end{array}$} & $\mathrm{P}>\mathrm{z}$ \\
\hline Glucose value $<70$ or $>200 \mathrm{mg} / \mathrm{dl}$ & 1,57 & 1,22 & 2,02 & 0,000 \\
\hline Insulin treatment & 0,81 & 0,62 & 1,05 & 0,116 \\
\hline Oral diabetic treatment & 0,96 & 0,71 & 1,30 & 0,792 \\
\hline age & 1,01 & 1,00 & 1,02 & 0,014 \\
\hline Gender (F vs M) & 0,93 & 0,75 & 1,14 & 0,486 \\
\hline Admission (ER vs elective) & 1,16 & 0,92 & 1,46 & 0,202 \\
\hline Medical vs surgical & 1,89 & 1,45 & 2,47 & 0,000 \\
\hline APR-DRG (ICD9) & 1,25 & 1,16 & 1,35 & 0,000 \\
\hline Charlson Index & 1,28 & 1,13 & 1,44 & 0,000 \\
\hline
\end{tabular}

\section{DISCUSSION}

Diabetic subjects with or without a history of severe hypoglycemia are more likely to fall than those without diabetes. Not only in elderly patients, but this risk is more pronounced in people younger than $65 \mathrm{y} / \mathrm{o}$, and previous studies on the relation between glycemic control and the risk of falls have been inconclusive. Our data suggests that not only hypoglycemia but also modest hyperglycemia (with values only more than 200 mg/ dl) are indicators of risk for falls among the hospitalized population. This risk is increased if the degree of metabolic compensation is worse with a direct relation between the number of value of glycemic blood test out of range and risk of falls. This increased risk is independent from for sex, age, admission to hospital (from ER/elective), surgical or medical, and severity of discharge diagnosis. 